\title{
HYOU1 wt Allele
}

National Cancer Institute

\section{Source}

National Cancer Institute. HYOU1 wt Allele. NCI Thesaurus. Code C50975.

Human HYOU1 wild-type allele is located within 11q23.1-q23.3 and is approximately $13 \mathrm{~kb}$

in length. This allele, which encodes hypoxia up-regulated protein 1 , is involved in the cytoprotective response to hypoxia-induced cellular perturbation. 